\title{
Chromaffin cell transplantation for neuropathic pain after spinal cord injury: a report of two cases
}

This article was published in the following Dove Press journal:

Journal of Neurorestoratology

13 February 2017

Number of times this article has been viewed

\author{
Lin Chen ${ }^{1,2}$ \\ Haitao $\mathbf{X i}^{1}$ \\ Juan Xiao' \\ Feng Zhang' \\ Di Chen' \\ Hongyun Huang ${ }^{1,3}$ \\ 'Cell Therapy Center, Beijing \\ Hongtianji Neuroscience Academy, \\ ${ }^{2}$ Department of Neurosurgery, \\ Tsinghua University Yuquan Hospital, \\ ${ }^{3}$ Neurorestoratology Institute, \\ General Hospital of Chinese People's \\ Armed Police Forces, Beijing, People's \\ Republic of China
}

Correspondence: Hongyun Huang

Cell Therapy Center, Beijing Hongtianji

Neuroscience Academy, Lingxiu Building,

No.I Gucheng Street, Beijing I00I43,

People's Republic of China

Tel +86 I39 I0II 6608

Email hongyunh@gmail.com
Abstract: Neuropathic pain (NP), a common secondary complication following spinal cord injury (SCI), presenting at or below the level of injury is largely refractory to current pharmacological, physical, and surgical treatments. Previous studies have demonstrated the promising value of cell therapy including adrenal chromaffin cells that have the capacity to act as mini-pumps that release amines and peptides for alleviating chronic pain. The paper presents the cases of two gentlemen suffering from severe central NP after thoracic SCI. Six months after chromaffin cell intrathecal injection, their pain relieved significantly. The results demonstrated the preliminary therapeutic efficacy of chromaffin cell transplants in people with $\mathrm{NP}$, and support further research of this treatment strategy for the management of intractable chronic pain due to SCI.

Keywords: chromaffin cell, cell transplantation, neuropathic pain, spinal cord injury

\section{Introduction}

Neuropathic pain (NP) can result from a lesion or a peripheral or central somatosensory system disease. NP is one of the important medical challenges, since it is very difficult to treat and the treatment is often ineffective. The majority of therapeutic analgesics including strong opioids and nonpharmacological approaches, such as transcutaneous electrical nerve stimulation, percutaneous electrical nerve stimulation, repetitive transcranial magnetic stimulation, supportive psychotherapy, and cognitive-behavioral therapy, do not often relieve the pain experienced by the patients. ${ }^{1,2}$ Providing adequate treatment for spinal cord injury (SCI)-induced NP still remains an unresolved problem, although pharmacotherapy treatments of morphine, anticonvulsants, antidepressants, and antiepileptics, combined with acupuncture. ${ }^{3}$

Cell transplantation is a potentially powerful approach for the alleviation of chronic pain. Cell therapies including stem cells (SCs) have been used for alleviating the NP induced by SCIs. Olfactory ensheathing cell, bone marrow mesenchymal stromal cell, umbilical cord mesenchymal stromal cell, and neural stem/progenitor cell transplantations alleviated the symptoms of NP and resulted in subsequent motor recovery after SCI. ${ }^{4-9}$ Intrathecal transplantation of embryonic SC-derived spinal gamma-aminobutyric acid-ergic (GABAergic) neural precursor cells attenuates NP in an SCI rat model. ${ }^{10}$

In fact, the clinical outcome of the aforementioned cell therapy is usually modest for severe NP following SCI; therefore, different strategies are being used to improve the efficacy. Since the early 1980s, chromaffin cell transplants have been explored as a promising alternative in different pathological states, mainly Parkinson's disease 
(PD) and chronic pain. Advances have been significant, since transplants have been performed in humans. The general mechanism of these grafts relies on the capacity of chromaffin cells to act as mini-pumps that release amines and peptides. ${ }^{11}$ This paper reports on the practice of using chromaffin cell transplants for refractory and severe SCI-induced NP in clinical setting.

\section{Methods and results}

The study was approved by the relevant research ethics committee of Beijing Hongtianji Neuroscience Academy. Both patients gave written informed consent for the study, according to the Declaration of Helsinki.

\section{Patient I}

Mr. KKT, a 62-year-old right-handed gentleman from Indonesia, presented with a history of sensory and motor disturbance in both lower extremities for four years and one month. He suffered a wound in a fall down from stairs on July 6, 2006. At that time, he felt pain only on the back. He stood up and walked several steps. Two minutes later, he began to lose sensation on limbs and he could not move his legs. He was sent to the emergency department of local hospital and spine magnetic resonance imaging (MRI) test showed SCI (at the level of thoracic vertebrae 7-9). Surgery of internal fixation was done immediately. After the operation, he was transferred to a hospital in Singapore and was again operated for internal fixation. Later, he felt pain on the back and had to take strong pain killers. Then he was transferred back to a local rehabilitation hospital and received rehabilitation therapy. After the therapy, his muscular tension got better. Later on, he was discharged and continued doing rehabilitation exercises. He complained of the back pain which was evaluated using visual analog scale/score (VAS) ${ }^{12}$ and International Association of Neurorestoratology Spinal Cord Injury Functional Rating Scale (IANR-SCIFRS) pain score ( 0 point means severe pain and 3 points means no pain). ${ }^{13}$ The patient had a VAS score of 10 points and IANR-SCIFRS score of 0 points.

\section{Physical examination}

Physical examination of the patient showed that his general condition was fair and mental status was normal. There were no abnormal signs in his head, chest, and abdomen. Motor power: upper extremities $5 / 5$ bilaterally; lower extremities: hip flexors were $0 / 5$ on the right and $0 / 5$ on the left; knee extensors were $0 / 5$ on the right and $0 / 5$ on the left; ankle dorsiflexors, long toe extensors, and ankle plantar flexors were $0 / 5$ bilaterally. Light touch disappeared from T8 level on the right. Light touch disappeared from T7 level on the left. Pinprick decreased from T5 level on the right and T6 level on the left, disappeared from T6 level on the right and T7 level on the left. The biceps reflex, triceps reflex, and radial periosteal reflex were $2+$ bilaterally. Knee jerk and Achilles reflex disappeared bilaterally. The abdominal reflex was absent. The patella clonus was negative bilaterally and ankle clonus was positive bilaterally. Hoffmann sign and Babinski sign were negative bilaterally. He was able to perform alternate motion test and finger-nose test. He was unable to perform heel-knee-tibia test. Sweating function decreased from the damaged level obviously.

\section{Cell preparation}

Aborted fetus (12 gestational weeks) with adrenal taken under sterile conditions was quickly placed in Hanks solution at $4^{\circ} \mathrm{C}$. The adrenal cortex and medulla were repeatedly washed and blunt dissected. Separated medullary tissue was taken in a plate and cut into pieces, and then was collected into a centrifuge tube. Approximately, $2 \mathrm{ml}$ of $0.25 \%$ trypsin was added and placed in a water bath at $37{ }^{\circ} \mathrm{C}$ for digestion, taken 20 minutes after repeated pipetting and then $2 \mathrm{ml}$ stop solution was added to stop digestion. Stainless steel filter was used to collect the filtrate in a centrifuge tube and centrifuged at $1500 \mathrm{rpm}$ for 5 minutes. The supernatant was discarded, cell counts by trypan blue. Cells were suspended in $10 \%$ fetal bovine serum and stored in the refrigerator at $4^{\circ} \mathrm{C}$ for further analysis.

\section{Injection procedure}

Lumbar puncture (LP) was performed by the procedure followed routinely. After releasing $10 \mathrm{ml}$ of cerebrospinal fluid slowly, one million chromaffin cells $+5 \mathrm{ml}$ normal saline + $5 \mathrm{mg}$ dexamethasone injection were injected slowly.

\section{Follow-up}

The patient's recovery process was good. No headache, fever, and other adverse events occurred. Cyclosporin A (CsA, $4 \mathrm{mg} / \mathrm{kg} /$ day) was taken for one month. After the first day of treatment, his pain was relieved. One week later, VAS score was 1 point. After six months of follow-up, both VAS and IANR-SCIFRS pain scores were 2 points each, and the results were satisfactory.

\section{Patient 2}

Mr. ZXZ, a 54-year-old right-handed gentleman from the People's Republic of China, presented with a history of sensory and motor disturbance in both lower extremities for two 
years and nine months. He suffered a wound in a fall down from $10 \mathrm{~m}$ high on September 26, 2010. He was sent to the emergency department of a local hospital. Spine computer topography (CT) and MRI tests showed SCI (at the level of thoracic vertebrae 3-5). The patient underwent the surgery for decompression of the spinal cord with internal fixation smoothly. After the operation, he was treated with acupuncture, massage, and rehabilitation training. One month later, he had chest and back pain, which needed to be relieved by taking strong medicines. At this admission, the patient complained of pain, with VAS and IANR-SCIFRS pain scores of 10 and 0 points, respectively.

\section{Physical examination}

General condition was fair. Tension in the muscles of his lower limbs increased. Motor power: upper extremities $5 / 5$ bilaterally; lower extremities: hip flexors were $0 / 5$ on the right and $0 / 5$ on the left; knee extensors were $0 / 5$ on the right and $0 / 5$ on the left; ankle dorsiflexors, long toe extensors, and ankle plantar flexors were $0 / 5$ bilaterally. Light touch disappeared from $\mathrm{T} 5$ level on the right. Light touch disappeared from T6 level on the left. Pinprick disappeared from T5 level on the right and T6 level on the left. The biceps reflex, triceps reflex, and radial periosteal reflex were 2+ bilaterally. Knee jerk and Achilles reflex were $3+$ bilaterally. The abdominal reflex was absent. The patella clonus was negative bilaterally and ankle clonus was positive bilaterally. Babinski sign was positive bilaterally.

\section{Cell preparation, injection procedure, and follow-up}

Cell preparation and injection procedure were performed as described previously, and the number of transplanted chromaffin cells also reached one million. The recovery process was good. No adverse events were observed. CsA capsules were taken orally for one month with the dosage of $4 \mathrm{mg} / \mathrm{kg} /$ day. One week later, VAS decreased to 2 points. After six months of follow-up, the VAS and IANR-SCIFRS pain scores were 2 points each.

\section{Discussion}

Our case report provides new clinical evidence that adrenal medullary chromaffin cells administered directly into the spinal subarachnoid space is safe and effective for the very severe NP patients following SCI.

Human SCI is frequently associated with chronic pain that is severe and refractory to medical therapy. Following $\mathrm{SCI}$, chronic pain is a common secondary complication with NP cited as one of the most distressing and debilitating conditions leading to poor quality of life, depression, and sleep disturbances. NP presenting at or below the level of injury is largely refractory to current pharmacological and physical treatments. A most recent systematic review and meta-analysis have reported that the prevalence of NP post$\mathrm{SCI}$ is $53 \%$ and that it is more common in some conditions, such as below the level of lesion, in patients with tetraplegia, in older patients, and at one year post-injury. ${ }^{14}$ The most common pain characteristic of NP was pricking pain followed by electrical pain and numbness. The mean VAS score of at-level NP was 7.5 and that of below-level NP was 6.8. All the patients suffered from rest pain, but 18 (54.6\%) patients with at-level NP and 20 (50.0\%) patients with below-level NP suffered from evoked pain. ${ }^{15}$

Traumatic SCI has been shown to trigger structural atrophic changes within the spinal cord and brain, sensory fiber sprouting. The directionality of these relationships reveals specific changes across the neuroaxis (i.e. atrophic changes versus increases in volume) and may provide substrates for the underlying neural mechanisms in the development of NP. ${ }^{16,17}$

Anticonvulsants remain the most studied and supported pharmacotherapy for NP post-SCI. Antidepressants likely showed reduction in pain only among those with comorbid depression. Botulinum toxin and phenol blocks were given as supports for the reduction of mixed pain post-SCI. ${ }^{18}$ Despite advances in our understanding of the mechanisms contributing to this type of pain and an increasing number of trials examining the treatment efficacy, our ability to relieve SCI-induced NP is still very limited. ${ }^{19}$

A number of preclinical studies have demonstrated the value of adrenal medullary allografts in the management of chronic pain. As biological or living mini-pumps, these cells produce and secrete pain-reducing neuroactive substances. A phase II open study has demonstrated the feasibility and the safety of the approach using chromaffin cell grafts for longterm relief of intractable cancer pain. ${ }^{20,21}$ Literature has shown that transplantation of adrenal medullary tissue or isolated chromaffin cells can reduce pain sensitivity, and autopsy tissue obtained from two patients revealed viable transplanted chromaffin cells. ${ }^{22}$ Immunocytochemical microscopy showed neuroendocrine cells positive for chromagranin A, and for enzymes tyrosine hydroxylase and dopamine-beta-hydroxylase. There was a relationship between analgesic effect, Met-enkephalin levels, and the presence of chromaffin cells surviving in cerebrospinal fluid. ${ }^{23} \mathrm{~A}$ study of rat models of excitotoxic SCI showed that adrenal medullary transplants reduced pain-related behaviors. ${ }^{24}$ So, chromaffin cells may offer a nonablative alternative for NP following SCI. 


\section{Conclusion}

Collectively, our data indicate that adrenal medullary chromaffin cells by the route of LP may have therapeutic value in intractable chronic pain for patients following SCI.

\section{Acknowledgment}

The authors thank the two patients who participated in this research.

\section{Disclosure}

The authors report no conflicts of interest in this work.

\section{References}

1. Daszkiewicz A, Gierlotka Z, Nierodziński W, Misiołek A, Misiołek $H$. Neuropathic pain after spinal cord injury resistant to conventional therapies - case report. Psychiatr Pol. 2016;50(2):345-355.

2. Nardone R, HöllerY, Langthaler PB, et al. rTMS of the prefrontal cortex has analgesic effects on neuropathic pain in subjects with spinal cord injury. Spinal Cord. Epub 2016 May 31.

3. Gwak YS, Kim HY, Lee BH, Yang CH. Combined approaches for the relief of spinal cord injury-induced neuropathic pain. Complement Ther Med. 2016;25:27-33.

4. Chen L, Huang H, Sharma HS, Zuo H, Sanberg P. Cell transplantation as a pain therapy targets both analgesia and neural repair. Cell Transplant. 2013;22(Suppl 1):S11-S19.

5. Huang H, Chen L, Sanberg P. Cell therapy from bench to bedside translation in CNS neurorestoratology era. Cell Med. 2010;1(1):15-46.

6. Huang H, Sun T, Chen L, et al. Consensus of clinical neurorestorative progress in patients with complete chronic spinal cord injury. Cell Transplant. 2014;23(Suppl 1):S5-S17.

7. Huang HY, Mao GS, Chen L, Liu AB. Progress and challenges with clinical cell therapy in neurorestoratology. J Neurorestoratology. 2015; 3:91-95.

8. Yousefifard M, Nasirinezhad F, Shardi Manaheji H, Janzadeh A, Hosseini M, Keshavarz M. Human bone marrow-derived and umbilical cord-derived mesenchymal stem cells for alleviating neuropathic pain in a spinal cord injury model. Stem Cell Res Ther. 2016;7:36.

9. Watanabe S, Uchida K, Nakajima H, et al. Early transplantation of mesenchymal stem cells after spinal cord injury relieves pain hypersensitivity through suppression of pain-related signaling cascades and reduced inflammatory cell recruitment. Stem Cells. 2015;33(6):1902-1914.
10. Hwang I, Hahm SC, Choi KA, et al. Intrathecal transplantation of embryonic stem cell-derived spinal GABAergic neural precursor cells attenuates neuropathic pain in a spinal cord injury rat model. Cell Transplant. 2016;25(3):593-607.

11. Ambriz-Tututi M1, Monjaraz-Fuentes F, Drucker-Colín R. Chromaffin cell transplants: from the lab to the clinic. Life Sci. 2012;91(25-26): 1243-1251.

12. Bourdel N, Alves J, Pickering G, Ramilo I, Roman H, Canis M. Systematic review of endometriosis pain assessment: how to choose a scale? Hum Reprod Update. 2015;21(1):136-152.

13. Huang H, Xi H, Chen L, Zhang F, Liu Y. Long-term outcome of olfactory ensheathing cell therapy for patients with complete chronic spinal cord injury. Cell Transplant. 2012;21(Suppl 1):S23-S31.

14. Burke D, Fullen BM, Stokes D, Lennon O. Neuropathic pain prevalence following spinal cord injury: a systematic review and meta-analysis. Eur J Pain. Epub 2016 Jun 24.

15. Jang JY, Lee SH, Kim M, Ryu JS. Characteristics of neuropathic pain in patients with spinal cord injury. Ann Rehabil Med. 2014;38(3): 327-334.

16. Jutzeler CR, Huber E, Callaghan MF, et al. Association of pain and CNS structural changes after spinal cord injury. Sci Rep. 2016;6: 18534.

17. Detloff MR, Quiros-Molina D, Javia AS, et al. Delayed exercise is ineffective at reversing aberrant nociceptive afferent plasticity or neuropathic pain after spinal cord injury in rats. Neurorehabil Neural Repair. 2016;30(7):685-700.

18. Mehta S, McIntyre A, Janzen S, Loh E, Teasell R; Spinal Cord Injury Rehabilitation Evidence Team. Systematic review of pharmacological treatments of pain after spinal cord injury: an update. Arch Phys Med Rehabil. 2016;97(8):1381-1392.

19. Siddall PJ, Middleton JW. Spinal cord injury-induced pain: mechanisms and treatments. Pain Manag. 2015;5(6):493-507.

20. Lazorthes Y, Sagen J, Sallerin B, et al. Human chromaffin cell graft into the CSF for cancer pain management: a prospective phase II clinical study. Pain. 2000;87(1):19-32.

21. Jozan S, Aziza J, Châtelin S, et al. Human fetal chromaffin cells: a potential tool for cell pain therapy. Exp Neurol. 2007;205(2):525-535.

22. Pappas GD. Fine structure of host-graft relationships between transplanted chromaffin cells and CNS. FASEB J. 1999;13(Suppl 2): S277-S280.

23. Bés JC, Tkaczuk J, Czech KA, et al. One-year chromaffin cell allograft survival in cancer patients with chronic pain: morphological and functional evidence. Cell Transplant. 1998;7(3):227-238.

24. Brewer KL, Yezierski RP. Effects of adrenal medullary transplants on pain-related behaviors following excitotoxic spinal cord injury. Brain Res. 1998;798(1-2):83-92.
Journal of Neurorestoratology

\section{Publish your work in this journal}

The Journal of Neurorestoratology is an international, peer-reviewed, open access online journal publishing original research and review articles on the subject of Neurorestoratology. To provide complete coverage of this revolutionary field the Journal of Neurorestoratology will report on relevant experimental research, technological advances,

\section{Dovepress}

and clinical achievements. The manuscript management system is completely online and includes a very quick and fair peer-review system, which is all easy to use. Visit http://www.dovepress.com/testimonials. php to read real quotes from published authors. 